\title{
The Neglected World of the Workplace Trainer
}

\author{
Marwa Elshafie \\ Training and Development Section, MOI, Qatar \\ E-mail: marwaasg@gmail.com
}

Received: 10-02- 2013

Accepted: 22-03-2013

Published: $30-04-2014$

doi:10.7575/aiac.ijels.v.2n.2p.31

URL: http://dx.doi.org/10.7575/aiac.ijels.v.2n.2p.31

\begin{abstract}
The aim of this small-scale research is to explore the hidden world of the workplace trainer. Four trainers from a training institute in Qatar were interviewed and asked about their opinions of the employee as a learner, the trainer's work, and the role of quality compliance in the training process. After transcribing and analysing the semi- structured interviews, several themes concerning the employee as a learner emerged such as the employees' motivation and the effects of the workplace environment on learning. The findings also showed the trainers' need for an adequate professional development plan and a reconsideration of their power inside the classroom. Regarding the quality compliance, there were various insights and suggestions for improvement. The results of this study are important to any workplace trainers, human development, and quality compliance employees or anyone interested in knowing more about the world of adult learning.
\end{abstract}

Key words: Workplace training, Teacher- student interaction, Adult learning, Quality compliance, Trainers' power

\section{Introduction}

Recently, there has been a great emphasis on workplace learning. Globalization, the constant change in technology, the fierce competitions between companies, and the employees' skills gap are among the reasons for this interest. In the words of Chan $(2010$, p. 25): "in order to survive in the global economy, businesses need to invest in advanced technology, modern machinery, and human capital to keep up with the changes in this volatile environment." One way of investing in human capital is to provide constant and appropriate training in the workplace. According to Boud $(1998$, p. 7) the workplace learning has two advantages: it increases the individual's knowledge and helps in developing the organization:

The workplace is becoming the site of both learning associated with enhancing the development of the enterprise through contributing to production, effectiveness, and innovation, and to the development of individuals through contributing to knowledge, skills, and the capacity to further their own learning with respect to their roles as employees and as citizens in wider society.

According to Candy and Matthews (1998, p. 12) researching workplace learning is a complex process as it can be studied from different fields, different perspectives, different contexts and with the use of various methods:

Coming from a range of fields of study (adult education, higher education, cultural anthropology, organizational theory, innovation studies, industrial economics, management studies, vocational education, etc.), a variety of theoretical perspectives (behaviourism, interpretivism and critical theory), different points of view (the manager, the learner/worker, the development practitioner). (See also Matthews, 1999; Smith, 2003; Vaughan, 2008; Tynjälä, 2008).

Training in the workplace can take several forms. According to Jacobs (2008), there are five approaches to workplace Training:

1. "Off -the- Job" training offers courses on several topics that are useful for any workplace (e.g., soft skills courses) at a location away from the workplace.

2. "On- the -Job" training (OJT) is mostly informal and unstructured where the supervisor or a fellow employee shows another employee the knowledge required for performing a certain job inside the worksite.

3. "Structured-on- the- Job" training (S-OJT) is a planned training with clear objectives and outcomes where an experienced employee trains another employee at the worksite. Although the S-OJT should ideally be one-onone training, it can also involve more than one trainee.

4. "Just- in-time" training (JITT) where the training focuses on the information needed to perform a specific task at a point of time (when needed) and at a specific location (in the work setting). This training can use several approaches like S-OJT, web- based material or a classroom presentation if needed.

5. A blend of S-OJT and off- the- job training is where the workplace managers and supervisors agree on the set of skills and knowledge needed to perform the work. Then, they arrange for experts to teach these required skills in a classroom / laboratory training programmes. 
(see also Risnick, 1987; Marsick \& Walkins, 1990; Eraut, 2004; Tynjälä, 2008; Vaughan 2008).

This study focuses on the blended S-OJT and off-the- job training where the employees joined a planned job related vocational training followed by applications in the workplace. Typically, the employees attend the classes for a couple of hours and then return back to continue their work.

\subsection{Situation in Qatar}

Qatar is a small country in the Gulf area, rich in natural resources but with a small number of citizens. According to Gonzalez, Karoly, Constant, Salem and Goldman (2008, p.27) non-nationals make up around 88 percent of the labour force. The Qatari leadership is trying to increase the employment of the Qatari nationals in both the governmental and the private sectors. In the words of Gonzalez et al., (2008, p.52), private companies prefer not to hire Qataris as they are lacking "knowledge about information technology or other computer skills, finance and accounting, marketing and public relations, English language skills, and engineering." (See also Berrebi, Martorell \& Tanner, 2009).

There are several reasons for the small number of Qatari employees in the private sector. First, the Qataris expect the private companies to pay them high salaries with shorter working hours as is the case in the government sector. Second, as the schools and universities are not preparing them well for the jobs (see also Jolo, 2005; Stasz et al., 2008), they need intensive preparation in English language and on the job training. Another concern is that the majority of the Qatari graduates major in the Arts subjects. Therefore, the Qataris either prefer to work in the government or they are "insufficiently skilled" to work in the private sector (Berrebi, Martorell \& Tanner, 2009).

In order to increase the employment of Qataris in the private sector, the Qatari leadership has implemented several initiatives. For example, they have made a total primary and secondary school educational reform (see Frank, 2006; Stasz et al., 2008; Berrebi, Martorell \& Tanner, 2009). They also introduced the process of Qatarization where "a vacant position must be first offered to a Qatari national; then, if it cannot be filled, it can be offered to a non-Qatari Arab, followed by a non-Arab foreigner"( Winckler , 2000 as cited in Gonzalez et al., 2008, p. 78). In addition, according to the Qatari policy at least 20 percent of employees in all sectors should be Qatari.

In order to provide Qataris with the skills needed in the workplace, training before and during the job is organised. According to a report published by the Permanent Population Committee (2012), training sessions in the private sectors increased by $128 \%$ between the years 2009 and 2011 . Furthermore, the number of trainees increased by $33 \%$ between 2009 and 2011.Training is in the form of private training institutes (around 106 centres) which teach English, computers and any work requirements. In addition, some companies like Qatar Petroleum and Qatar Petrochemical provide on the job training for their employees to meet their work requirements.

\subsection{The context}

The institution under study was established in 2009 to promote the skills of the technical staff in a governmental company with four hundred employees. The training building consists of two floors. The first floor has the classrooms, the library, and the trainers' offices. The second floor has the laboratories and the conference room. Located inside the company campus, the employees leave their job to attend the courses and return back to continue working. There are 7 full- time teachers and 2 part-timers. The trainers are from Egypt (6), India (2), and Sudan (1). They teach technical English, Math, Networking, and Office Applications. One of the perquisites for the trainer's job is having experience in teaching at the college level preferably in the territory. The institute also tends to invite trainers from other institutes to give lectures and introduce new concepts or technology.

In 2011, the Strategic Planning Department (formally known as the quality compliance section) became one of the main departments in the subject institution. Business dictionary online defines quality audit as "a periodic, independent and documented examination and verification of activities, records, processes, and other elements of a quality system to determine their conformity with the requirements of a quality standard such as ISO 9000." There are five employees in the department (four males and one female). They all come from different educational backgrounds (mechanical engineering, statistics, and commerce) but they have certificates in quality assurance. Their main duty is to make sure that every activity is documented properly according to quality standards. They are in charge of designing the forms that will be filled in by the employees in different departments (including the training centre). Then, they come every month to do their auditing.

\subsection{Aim of the study}

Despite the increase in the numbers of training institutes in Qatar, little is yet known about the workplace trainers. The interest in the study comes from the fact that there is much research on employee satisfaction and how to improve the courses, while the trainer's views about the quality compliance or the employee as a leaner in general are not sought and thereby largely ignored. Knowing the challenges facing the trainer can help in improving the situation at the centre and in due course result in higher employee satisfaction. In addition, it will add to the body of knowledge as little has been written about workplace trainers in Qatar.

The situation in the subject centre is similar to the majority of the training centres in Qatar (e.g., Qatargas, Qatar Petroleum and Qatar Airways). Thus, the results from this study will be beneficial to other centres as well.

\section{Literature Review}

On examining the literature, the researcher focused on the studies that aimed at understanding the trainers' views about workplace training. Most of the studies were done in Australia and their main focus was on the changing role of the 
Technical and further education (TAFE) and vocational education and training( VET) educators. Hence, the importance of this study is that it aims at understanding workplace training in Qatar.

The study by Favro (2003) was done in a workplace context similar to the subject institute. The case study aimed at understanding the issues faced by teachers in one of the major training providers in Australia. It explored the changes to the teachers' role after implementing the Apprenticeship and Traineeship training system. It used three qualitative methods: focus group interviews, activity logs by the teachers and policy documents examined by the researcher. According to the Performance Agreement policy, the trainings should not only be on the job, but also structured where the trainees should be released from work to attend the training and the teachers have a clear planned training. This situation is similar to the subject institute of my research. Although the researcher has not mentioned how the data was analysed which might have effects on the credibility of the study, several important themes emerged. The findings of the focus group interviews showed that the employers were not cooperative in releasing the trainees for training, the teachers spent a lot of time travelling to the workplace, the teachers thought that the trainees were not learning transferable skills and the skills were so limiting to the particular workplace situation. Another important theme was the tension that the teachers felt for the quality audit demands:

standards introduced to ensure quality training were seen to be in conflict with, or 'negating' the teaching and the very personality of teachers who have their own construction of quality "Favro (2003: p.7).

The issues raised by the teachers in this study were similar to the findings of Harris, Simons and Moore (2005) study. The study explored the roles of (TAFE) practitioners working with and within private companies. The researchers chose a case study methodology and interviewed 34 TAFE practitioners. Despite the limitations of the study (its sole method of data gathering and the researchers' biases), the findings have added to the understanding of the TAFE context. Similar to the previous study, the findings showed that the TAFE practitioners working in private companies suffered from the quality audit demands " awful administrative nightmare" (ibid , p.28). The findings also showed the need for professional development plans for the TAFE staff.

The findings of the previous studies were similar to those found in Davids (2012) study. The researcher explored the needs of TAFE Queensland's lead vocational teachers. Despite the limitations of the study (e.g., the use of focus group interviews only), the findings were very important. According to the focus group interview, the trainers were frustrated with the quality audit demands. Many of the trainers expressed how they were overwhelmed by the paperwork "which does not reflect the quality of their teaching, the integrity of their work or the qualitative outcomes of their work with the students" (Davids, p.14). It was also mentioned that only a few teachers were given the chance to attend professional development training due to the costs involved.

Likewise, the need of professional development plans for the workplace trainers was common among other studies. For example, Harries et al. (2003) conducted a study to understand the changing role of the (VET) trainers working in Australian public and private organisations. Although the data in this study was gathered through the use of mixed methods (i.e surveys, interviews with HR personal), the researchers should have interviewed some trainers to increase the depth of the study. The findings of the survey showed that the chances for the trainers' professional development were better in the public sector. However, according to the study "staff development provisions appear to be inadequate for meeting demands at the present time. This is especially true for non-permanent staff who deliver the majority of training programs in many training providers" (Harries et al., p.63).

The current study makes an attempt to bridge the gap in the literature by understanding the world of workplace trainers in Qatar. Unlike the previous studies, it asks direct questions about the workplace learner, the trainer's situation, and the relation between the trainer and the quality compliance. All the research questions were based on the trainers' situation in the subject institute and the researcher's interest to shed the light on the workplace training in Qatar.

\section{Theoretical Framework}

This study is exploratory and belongs to the interpretive paradigm. The research is informed by the ontology, epistemology, and methodology of the interpretive paradigm. The interpretivist ontology is "anti- foundationalist, and subscribes to the view that the world does not exist independently of our knowledge of it" (Grix, 2004: 83). According to Guba (1990, p.26), the interpretivist epistemology is subjective and "if realities exist only in respondents' minds, subjective interaction seems to be the only way to access them." Guba (1990, p. 27) explains the interpretivist methodology as "hermeneutic and dialectic: individual constructions are elicited and refined hermeneutically, and compared and contrasted dialectically."

\subsection{The purpose}

The study explored the world of the workplace trainers in Qatar. It aimed at answering the following research questions from the trainers' perspectives:

1. How is the employee as a learner different from the college student?

2. What are the similarities / differences between the workplace trainer and the college instructor?

3. What are the trainers' views of quality compliance?

4. What are the trainers' suggestions for improvement?

\section{Methodology}

According to Yin (2003,p.2) the case study methodology, "allows investigators to retain the holistic and meaningful characteristics of real-life events- such as individual life cycles, organizational and managerial processes, neighborhood 
change, international relations, and maturation of industries." As the researcher's aim was to understand "the case in depth" from the trainers' perspective, the case study is the most appropriate methodology (Richards, 2003; Perry, 2005; Dornyei, 2007; Punch, 2009; Cohen et al., 2011; Creswell, 2012). It also matches the interpretive nature of the research.

\subsection{Participants}

After getting the manager's consent, the trainers were invited to participate in the research. Four trainers agreed to take part in the research.

\section{Trainer 1}

He is an Egyptian engineer (45 years old). He has been working in the institute since 2010. Before joining the institute, he was teaching at the Qatari military forces for seven years. After his graduation, he worked as lecturer in a college in Egypt for 5 years. He is currently teaching networking.

\section{Trainer 2}

He is an Egyptian majoring in electronics (25 years old). He worked as a teacher assistant in a university in Egypt for 5 years and he joined the institute in 2012. He teaches math and introduction to electronics.

\section{Trainer 3:}

He is Indian with a bachelor's degree in telecommunications (35 years old). He has been working in the institute for 3 years. Before that he taught in a private technical institute in India for 12 years. He is teaching networking and telecommunications.

\section{Trainer 4}

He is Sudanese / American (50 years old) and he has a master degree in engineering. He worked as a lecturer in a community college in the USA for three years. He also worked as a lecturer in the Qatari military college for eighteen years. He has been working in the institute since 2009 where he teaches math and electronics.

\subsection{Method}

Semi- structured interviews were used with the four trainers. Being a trainer herself, the researcher was already aware of the situation in the training centre and was able to prepare some general open-ended questions. Thus, it is the most appropriate method as Dornyei $(2007$, p. 136) notices that it "is suitable for cases when the researcher has a good enough overview of the phenomenon or domain in question and is able to develop broad questions about the topic in advance."

The semi-structured interview also matched the interpretivist epistemology of the study as Kvale (2007, p. 10-11) asserts that it "attempts to understand themes of the lively daily world from the subject's own perspectives. This interview seeks to obtain descriptions of the interviewees' lived world with respect to interpretation of the meaning of the described phenomena."

\subsection{Procedures}

Before conducting the interviews, the consent was taken from the institution's authorities and the purpose of the study was explained. Four trainers agreed to be interviewed and sought to be anonymous. An interview guide (Appendix 1) was piloted then distributed one day before the interview.

Before conducting the interviews, the participants signed an informed consent form (Appendix 2 ). Three of the interviews were conducted in the interviewees' offices and one was in the library. Three of the interviews were conducted in Arabic and were translated by the researcher. Then, they were given to a certified translator to cross check them. The third interview with trainer 3 was in English. The interviews were conducted in June 2013 before the summer holidays and each lasted between 20 to 30 minutes.

\subsection{Data Analysis}

Data from the recorded interviews were gathered and transcribed by the researcher. The researcher asked the trainers to check the transcriptions, which served as a member check to increase the credibility of the study.

Thematic analysis was used in analysing the data. According to Gibson and Brown, (2009, p. 127) thematic analysis "refers to the process of analyzing data according to commonalities, relationships and differences across a data set.

Table 1. Summary of the Findings

\begin{tabular}{ll}
\hline Research questions & Themes \\
\hline Q. How is the employee as a learner different from the & $\bullet$ Motivation \\
college student? & $\bullet$ Family and work obligations \\
Q2. What are the similarities / differences between the & $\bullet$ Teacher- student's interaction \\
workplace trainer and the college instructor? & $\bullet$ Trainer's power \\
& $\bullet$ Professional development \\
Q3.What are the trainers' views of quality compliance? & $\bullet$ Material taught and course duration \\
& $\bullet$ The form design \\
\hline
\end{tabular}


Q4.What are the trainers' suggestions to improve the Suggestions to:

situation?

- The managers

- The quality compliance team

Question 1: How is the employee as a learner different from the college student?

Motivation was the first theme to emerge from the analysis. Three out of four trainers saw that the college student was more motivated than the employee. Demotivation results from the fact that the employee already had a job, the lack of clarity of the training's goals and the learning medium surrounding the employee.

The full time student might be more motivated as the environment surrounding him creates motivation. There are 200,300, 500 students competing with each other to get higher grades and get their certificates to continue their education. Unlike the employee, who is already working and taking his salary. It doesn't matter if he passes the course or not. (Trainer 1)

At college the student is motivated because he needs the certificate in order to work. Here there is no clear goal for the certificate. The employees see it as a routine or task that they are forced to finish in order to get promoted. (Trainer 2)

Trainer 3 had a different view. He thought that the employee as a student was more motivated because of the incentives given to him at work in the form of money or promotion. Unlike the college students who "get the motivation only from their parents to make their career better. And they don't get any monetary benefits." (Trainer 3)

Two trainers (1 and 3) thought that the family and work obligations were the reasons for the employee's lack of concentration in the classroom. Most of the time the employee is married and has social commitments which might occupy his mind. On the other hand, the college student's sole responsibility is studying. He is fully supported by his family to focus on his studies. In addition to family obligation, he might be thinking about his work as he has to go back to finish his duties after the classes.

Ok for the employee student it is not easy to take his time out and study because he sometimes has to steal some time from his family. But in the case of the college student, parents are giving him time to study (Cough) so for him it is easy to cover his syllabus. Here the employee is not off from his duty during the days of training. He has to check his emails and follow up his job. He has to follow up on his family. Therefore, it is difficult for him to get the time. (Trainer 3)

Unlike the previous trainers, trainer 2 and trainer 4 had a different opinion. They thought that the family and work obligations were not an excuse for the lack of concentration or studying. In fact, the employee has to time to study if he has the will.

He is busy because he wanted to be busy. If we considered that he has 7 hours of work, he has the rest of the day. He has time. However, he is always busy doing other things. His own life! (Trainer 2)

If they want to study they will find time. They are still young, but again comes the lack of motivation. (Trainer 4)

Another factor that might have influenced the employees' motivation was the non- educational medium surrounding them. All the trainers agreed that the college student had the advantage of being in an educational medium that encouraged studying.

Question 2: The difference between the workplace trainer and the college instructor.

The trainers believed that the teacher- student interaction was better at the workplace. The trainer's availability and friendly relations were the reasons for the better interaction. Part of this friendly relation was because the trainer and the employee were working together.

The workplace training there is no barrier of the teacher and the student kind of barrier. But in the colleges there is a barrier for the students, professors, principals, lectures .So, the students are not in a mood or may be hesitant to interact with the teacher sometimes. This is the first difference here in the workplace the employee student just they will talk to the employee student as their friends. (Trainer 3)

At the college, the relation is more formal. Here it has to be friendly as we are working together. I am a bit lenient. (Trainer 4)

A very important theme which emerged from the analysis was the trainer's power. The four trainers agreed on their lack of coercive power inside the classroom. Consistent with French and Raven (1968), McCroskey and Richmond (1983, p. 176) think that a teacher's coercive power "is based on a student's expectations that he/she will be punished by the teacher if he/she does not conform to the teacher's influence attempt." The punishment in the training context refers to the trainer's right to deprive someone from the course if he behaves badly or warn him if he is late or misses a class. Thus, if the trainers had any problems with their students, the manager only had the authority to take any measures. They also reported that the students knew about their lack of power even if they did not say it. The trainers related their students' reluctance to do the assignment and their lack of motivation to this lack of power.

The college teacher can take action on the student if they did not do the assignments. But, in the workplace he can't take any action. (Trainer 3) 
The lecturer in any university is respected. Here he still knows that you are an employee and sometimes he might be higher than you. This doesn't mean that he will treat you badly ... He respects you, but he knows that he can leave the course whenever he wants and you won't be able to do anything about it. He knows deep inside that you don't have power and you know that too. .. This is the truth. As long as this is the situation, nothing will change. (Trainer 2)

The four trainers mentioned that they were not given any teaching courses or training on the teaching aids (e.g., Smart board) except for the subjects they had to teach. They also complained about the lack of a clear professional development plan designed for them unlike the college lecturer.

Here the trainer like the course doesn't have a clear plan. At the college you have limited time to finish your professional development like the master and the Ph.D. Here there is no development for the trainer. There is no restriction. Here you can be the same after 10 years. You will be working in the same place and this is reflected on the students themselves. (Trainer 2)

Disparity in the students' levels and different educational backgrounds were considered as burdens on the workplace trainers.

One might have finished high school from 10 years and he doesn't remember anything and the other might be a fresh graduate who remembers everything. (Trainer 1)

Unlike the academic syllabus, the workplace syllabus is short and concise. It focuses on the applications rather than the theories. As for the course duration, it is much shorter than the academic year.

We don't teach theories. We concentrate on applications. The main aim of the course is to teach them new technologies or applications that they will use immediately in their work .Unlike college, where we teach theories that they might not use. (Trainer 4)

Question 3: The trainers' views of quality compliance.

The four trainers acknowledged the importance of the quality compliance in monitoring and improving the courses; however they had issues with how the quality control was managed. They believed that the quality control employees did not know the trainer's work and they were not cooperating with them. They also felt a sense of superiority from the quality control employees.

The quality control employee doesn't work as a police officer whose ultimate aim is to find mistakes in the employee's work. As if he is pointing a gun at his face all the time. This is wrong. (Trainer 1)

We are not working as a team. The quality control employee is waiting for my mistakes. We are enemies. (Trainer 2)

Only trainer 2 mentioned that the trainer's evaluation form was badly designed and it did not reflect the trainer's work. He thought that this kind of "one form fits all" was mainly because the quality audit team were not trainers and they did not know the proper criteria to evaluate a teacher.

\section{Question 4: Your views on how to improve the situation}

The trainers had several suggestions for the training centres managers and the quality compliance department. They advised the managers to make the training courses as a prerequisite to the promotion. They should encourage the employees to study by giving them time off work during the training. They also suggested that the managers should recognize the employee who passed the course successfully and warn the employee who failed the course (reward and punishment system) which can be done by promoting a healthy competitive spirit inside the company. In addition, they should choose the right employee for the training bearing in mind their backgrounds and their job requirements not only their availability for the courses.

Another issue is the choice of the right employer to fit into the job. This is a very important point. For example, if the trainee is an accountant and he is taking courses in accounting he will definitely like the course and his job. What we have is a mismatch between the employee's education and his current job that results in disliking the job. (Trainer 1)

Three out of four trainers thought that it was the managers' duty to promote a lifelong learning concept in the company. They should motivate the employee to learn for the sake of knowledge not only for the promotion.

It is a good thing to make passing the training course as a prerequisite to get the promotion. Yet, still the employees will see it as a task that needs to be done not as an opportunity to learn and increase my knowledge. In order to achieve this we need a total mind transformation. (Trainer 2)

Regarding the trainers, the managers should prepare a professional development plan for each trainer. The focus should not only be on the subject matter courses, but also some pedagogical courses to improve the trainers' skills in teaching. They also thought that they should be given some power.

There should a professional development program for the trainer. He should be sent to take courses. Develop the trainer and the department will be developed. (Trainer 2)

Since the trainers complained about the quality compliance employees' lack of knowledge about their work, they suggested two solutions to overcome this problem. First, one employee from each department could work as a quality compliance representative which would enable him to design the right forms. Second, the quality compliance employee 
should spend some time with each department before designing the forms to fully understand the situation in the department.

The quality control section should assign one employee from each department to be the quality control representative. If they want to monitor and prepare forms for an instructor, they should get an employee with the same educational background. In this way he will know exactly what to look for when observing an instructor inside the class. (Trainer 2)

It would be much better for the quality control employee to be from inside the department. He takes the standards and then adapted as per the situation. (Trainer 1)

\section{Discussion}

Lack of motivation was one of the important themes discussed in this study. If we look at the reasons that the trainers mentioned for the demotivation, we can see that the word "forced" was mentioned by two different trainers. It was clear from the interviews that the employees' opinions about the course were not sought and it was the manager's decision to assign them for the training. Involving the employees in deciding their own training will increase their motivating as Aik and Tway (2006, p.30) notice "to reduce inefficiencies with any kind of training, workers must understand the purposes of the training and how the training methods will increase their efficiency or improve task performance with real-world problems."

Furthermore, the managers and the trainers should understand that the employees are adult learners and their training should be prepared differently. One solution is to apply Knowles' (1990) theory of adult learning (Andragogy) when preparing the courses. York (2006, p.186) summarizes the theory as follows:

(a) adults need to know why they are learning something, (b) adults need to be self-directed, (c) adults bring more work-related experiences into the learning situation, (d) adults enter into a learning experience with a problem-centered approach to learning, and (e) adults are motivated to learn by both extrinsic and intrinsic motivators. (See also Knowles, Holton \& Swanson, 2005)

It is clear that if the employees are put in charge of their training, they will be more motivated to learn and attend the course. It is the role of the mangers and the trainers to empower the employee as Bisschoff and Govender (2007, p. 70) have stated, "managers and training providers must first change their attitude towards employee empowerment" (see also Matthews, 1999).

The trainers complained about their lack of coercive power. According to McCroskey and Richmond (1983, p. 178), "All teacher power is based on student perceptions. If the student does not perceive the teacher to have a certain type of power, a teacher's appeal to that power, whether direct or implied, is not likely to result in influence." And since the employees perceived that the trainers did not have power, they were reluctant to study or do the assignments. On examining the literature to find a relationship between the teacher's power and learning, the results showed that the use of coercive power was negatively associated with student satisfaction and learning( Jamieson \& Thomas, 1974), with motivation( Richmond, 1990), and with cognitive and affective learning( Richmond \& McCroskey, 1984). The key question here is whether the use of coercive power would yield a different result in the Qatari context or not. I do not think the trainers need coercive power here. What they need though is to apply Knowles adult theory and make the employees responsible for their own learning.

Lack of planned professional development for the trainer was another important theme mentioned. The trainers expressed their needs for professional development courses especially in teaching and training. They thought that the lecturers at the college had the privilege of a clear professional plan designed for them. On examining the literature, several studies mention the trainers' need for PD. For example, the results of Evans, Dovaston, and Holland (1990, p. 52) showed that "in only a small minority however, did there seem to be a systematic programme or 'policy' on the training of trainers." Moreover, even if the trainers took courses they were only technical training courses like the trainers in this study. When the trainers were asked about the courses they would like to take, "Management courses were mentioned 31 times; advanced technical courses 16 times; training skills and methods 15 times; while 7 other types of courses were mentioned" (Evans, Dovaston, \& Holland, p. 51).

The suggestions given by the trainers in the current study were consistent with those given by the trainers in Davids (2012) study, where they stressed the needs for research and professional development courses for the teachers. They believed that both the organisation and the trainers would benefit from such training.

The trainers mentioned the lack of cooperation from the quality compliance employees and their lack of knowledge about the trainers work which resulted in inappropriate forms. This complaint was also mentioned in Davids (2012) study, where he quoted one of the trainers complaining about the quality audit requirement: "They develop a system and then we have to change what we do to fit the system (Ibid, p. 16).

Unlike other studies found in the literature, the trainers in the current study did not complain about the quality audit paperwork load. Only one trainer (2) mentioned that the trainer's evaluation form needed some changes to effectively capture the trainer's work.

Similar to the current study, several studies have mentioned the management support as an important indicator of the training success (see Bisschoff \& Govender, 2007; Skule, 2004; Rehman, Khan\& Khan, 2011). Two trainers in the current study mentioned the environment surrounding the college students and its relationship to encouraging learning and the learners' motivation. Creating an environment supporting learning and the managers' recognition of the 
employees' success in the training were among the suggestions mentioned. They also noted that the learning should be an incentive in itself and that the employers should encourage the employee to be a lifelong learner. These suggestions are confirmed in the study by Harris, Simons, and Bone (2000) where the trainers thought that the elements of a successful training program are supportive management, giving the employee time for training and spreading the awareness of lifelong learning.

\section{Conclusion}

The study aimed at understanding the world of the workplace trainer in Qatar. The findings showed that the trainers complained from demotivated learners, lack of an adequate professional development plan, lack of cooperation from the quality audit team and lack of coercive power.

Despite its exploratory nature, this study has useful insights into the workplace trainers, managers, and quality audit employers. First, the trainers and the managers of the workplace training should bear in mind that the employees are adult learners and should require certain conditions to ensure their learning. Second, the manager's support is a crucial condition for any successful workplace training. The support can be in the form of training incentives, promotions, and encouraging the culture of lifelong learning in the organisation. Third, the workplace trainers may be experts in their fields; yet they still need pedagogical courses in order to give successful training. Consequently, the managers should prepare a solid professional development plan for the trainers to improve the training quality. Fourth, the managers should consider giving the trainers some power inside the classroom that will help them with issues like class management. Finally, the quality audit team should consider the suggestion given by the trainers in this study to improve the training in the workplace.

\section{Limitations}

The study has the following limitations:

1. It is context bound to one institute in Qatar.

2. The trainers' views do not represent all the workplace trainers' views in the subject institute nor in Qatar.

3. The participants' gender is considered a limitation as the female trainers might have expressed different views.

4. The research is also limited in that the sole method of data gathering was through the use of semi- structured interviews.

5. The researcher's biases may have affected the interpretations.

In addition to the above limitations, the credibility of the study might have increased if the researcher interviewed college instructors and college students preferably in the Qatari context.

\section{Further Research}

Workplace learning is a very rich context for research. A quantitative study is needed to understand the trainers' problems. More research is needed to explore the relationship between the quality audit and the training improvement. Another study is needed to trace the management support's effect on the training and the effect of the trainer's power on the employees learning and motivation.

\section{References}

“Quality audit”2013. In BusinessDictionary.com. Retrieved August 25, 2013, from http://www.businessdictionary.com/definition/quality-audit.html

Aik, C. T., \& Tway, D. C. (2006). Elements and principles of training as a performance improvement solution. Performance Improvement, 45(3), 28-32. doi: 10.1002/pfi.2006.4930450307

Berrebi, C., Martorell, F., \& Tanner, J. C. (2009). Qatar's labor markets at a crucial crossroad. Middle East Journal, 63(3), 421-442. doi: 10.2307/20622929

Bisschoff, T., \& Govender, C. (2007). A management framework for training providers to improve workplace skills development in South Africa. Education, Knowledge and Economy, 1(1), 37-49. doi: 10.1080/17496890601128332

Boud,D. (1998). A new focus on workplace learning research. In D. Boud (Ed.), Current issues and new agendas in workplace learning (pp. 6-11). Leabrook: NCVER Ltd.

Braun, V., \& Clarke, V. (2006). Using thematic analysis in psychology. Qualitative Research in Psychology, 3(2), 77101. doi: 10.1191/1478088706qp063oa

Brooker, R., \& Butler, J. (1997). The learning context within the workplace: as perceived by apprentices and their workplace trainers. Journal of Vocational Education \& Training, 49(4), 487-510. doi: 10.1080/13636829700200028

Candy, P., \& Matthews, J. (1998). Fusing learning and work: Changing conceptions of workplace learning. In Boud,D. (Ed.), Current issues and new agendas in workplace learning (pp. 12-29). Leabrook: NCVER Ltd.

Chan, S. (2010). Applications of andragogy in multi-disciplined teaching and learning. Journal of Adult Education, $39(2), 25-35$.

Cohen, L., Manion, L., \& Morrison, K. (2007). Research methods in education. (6 th ed.). NY: Routledge.

Creswell , J. W. (2012). Educational research: Planning, conducting, and evaluating quantitative and qualitative research. (4 th ed.). Boston: Pearson Education. 
Dalton, J., \& Smith, P. J. (2004). Vocational education and training in secondary schools: Challenging teachers' work and identity. Journal of Vocational Education and Training, 56(4), 507-522. doi: 10.1080/13636820400200267

Davids, J. (2012). Have a heart: challenges for lead vocational teachers in the changing VET landscape. Adelaide: NCVER

Dornyei, Z. (2007). Research methods in applied linguistics: Quantitative, qualitative, and mixed methodologies. Oxford: Oxford university press.

Elo, S. and Kyngäs, H. (2008). The qualitative content analysis process. Journal of Advanced Nursing, 62:107-115. doi: $10.1111 /$ j.1365-2648.2007.04569.

Eraut, M. (2004b). Informal learning in the workplace. Studies in Continuing Education, 26(2), 173-247.

Eshach, H. (2007). Bridging in-school and out-of-school learning: Formal, non-formal, and informal Education. Journal of Science Education and Technology, 16(2), 171-190. doi: 10.2307/40188686

Evans, K., Dovaston, V., \& Holland, D. (1990). The changing role of the in-company trainer: An analysis of British trainers in the European community context. Comparative Education, 26(1), 45-59. doi: 10.2307/3099394

Favero, J. (2003). 'Quality' training: challenges for teachers of workplace training for trainees and apprentices. In E. Vocational \& A. Training Research Association (Eds.), The sixth Australian VET Research Association conference: the changing face of VET [refereed papers] (pp. 13p). [Nowra]: AVETRA.

Fenwick, T. (2010). Workplace 'learning' and adult education: Messy objects, blurry maps and making difference. European Journal for Research on the Education and Learning of Adults, 1(1-2), 79-95. doi: 10.3384/rela.2000-7426.rela0006

Frank, L. (2006). Qatar taps wells of knowledge. Science, 312(5770), 46-47. doi: 10.2307/3845964

Fuller, F. F. (1969). Concerns of teachers: A developmental conceptualization. American Educational Research Journal, 6(2), 207-226. doi: 10.2307/1161894

Gibson, W. J., \& Brown, A. (2009). Working with qualitative data. Los Ageles: SAGE Publications.

Gonzalez, G., Gabriella C., Lynn, A., Louay, C., Hanine, S., Charles, A. (2008). Facing human capital challenges of the 21 st century: Education and labor market initiatives in Lebanon, Oman, Qatar, and the United Arab Emirates. Santa Monica, CA: RAND Corporation. Retrieved from http://www.rand.org/pubs/monographs/MG786.

Grix, J. (2004). The foundation of research. London, Palgrave: Macmillan.

Guba, E. G. (1990). The paradigm dialog. California: Sage Publications.

Guba, E. G., \& Lincoln, Y. S. (1982). Epistemological and methodological bases of naturalistic inquiry. Educational Communication and Technology, 30(4), 233-252. Retrieved from http://www.jstor.org/stable/30219846 .

Guthrie, H., N. C. V. E. R., \& Clayton, B. (2010). Building capability in vocational education and training providers: the TAFE cut. Adelaide: NCVER.

Hager, P. (1998). Understanding workplace learning: General perspectives. In Boud,D. (Ed.), Current issues and new agendas in workplace learning (pp. 30-42). Leabrook: NCVER Ltd.

Harris, R., Clayton, B., \& Chappell, C. (2008). Supporting VET providers in building capability for the future: research activity overviews. Adelaide: NCVER.

Harris, R., Simons, M., \& Bone, J. (2000). More than meets the eye?: Rethinking the role of workplace trainer. Adelaide: NCVER.

Harris, R., Simons, M., \& Moore, J. (2005). 'A huge learning curve': TAFE practitioners' ways of working with private enterprises. Adelaide: NCVER.

Harris, R., Simons, M., Hill, D., Smith, E., Pearce, R., Blakeley, J., . . Snewin, D. (2001). The changing role of staff development for teachers and trainers in vocational education and training. Adelaide: NCVER.

Harris, R., Simons, M., Symons, H., Clayton, B. (2001). Ostriches, snakes or chameleons?: VET teachers/trainers and the changing nature of their work. In F. Beven, C. Kanes \& D. Roebuck (Eds.), Knowledge demands for the new economy: proceedings of the 9th annual international conference on post-compulsory education and training: volume one (pp. pp.267-276). Brisbane: Centre for Learning and Work Research.

Jacobs, L. R. (2003). Structured on the job training: Unleashing employee expertise in the workplace. (2nd ed.). San Francisco: Berrett- Koehler Publishers Inc.

Jamieson, D. W., \& Thomas, K. W. (1974). Power and conflict in the student- teacher relationships. The Journal of Applied Behavioral Science, 10(3), 321-336.

Jolo, H. A. (2005). Human capital formation: The case of Qatar. Journal of Business and Economics, 11, 67-93. Retrieved from http://hdl.handle.net/10576/8104

Kearney, P., Plax, T. G., Richmond, V. P., \& McCroskey, J. C. (1985). Power in the classroom III: Teacher communication techniques and messages. Communication Education, 34(1), 19-28. doi: 10.1080/03634528509378579 
Keller, J. M. (1987). Strategies for stimulating the motivation to learn. Performance + Instruction, 26(8), 1-7. doi: $10.1002 /$ pfi.4160260802

Kirpal, S., \& Wittig, W. (2009). Training practitioners in Europe: Perspectives on their work, qualification and continuing learning. Bremen: Institut Technik und Bildung, Universitat Bremen.

Knowles, M. (1984). Andragogy in action: Applying modern principles of adult learning.

Knowles, M. S., Holton III, F. E., \& Swanson, R. A. (2005). The adult learner: the definitive classic in adult education and human resource development. (6th ed.). Burlington: Elsevier Inc.

Kvale, S. (2007). Doing interviews. London: SAGE Publications Ltd.

Marsick, V. J., \& Watkins, K. E. (1990). Informal and incidental learning in the workplace. London: Routledge. Matthews, P. (1999). Workplace learning: Developing a holistic model. The Learning Organization, 6(1), 18-29.

McCroskey, J. C., \& Richmond, V. P. (1983). Power in the classroom I: Teacher and student perceptions. Communication Education, 32(2), 175-184. doi: 10.1080/03634528309378527

Miles, M. B., \& Huberman, A. M. (1994). An expanded sourcebook: Qualitative data analysis. (2nd ed.). Thousand Oaks: SAGE Publications.

Permanent Population Committee, (2012). Qatar population status 2012: Three years after launching the population policy. Retrieved from:

http://www.gsdp.gov.qa/portal/page/portal/ppc/PPC_home/ppc_news/ppc_files_upload/populations_status_2012_en.pd f

Perry, F.L. (2005). Research in applied linguistics: Becoming a discerning consumer. London: Lawrence Erlbaum Associates.

Population \& Social Statistics Department, Qatar Statistics Authority. (2009). Summary of training data. Retrieved from website: www.qsa.gov.qa/eng/surveys/Tranning-results-2009-Eng.pdf

Punch, K. F. (1998). Introduction to social research quantitative \& qualitative approaches. London: Sage Publications. Raelin, J. A. (1997). A Model of Work-Based Learning. Organization Science, 8(6), 563-578. doi: 10.2307/2635156

Rehman, A. U., Khan, A. M., \& Khan, R. A. (2011). Measuring training effectiveness: A case study of public sector project management in Pakistan. Journal of Diversity Management, 6(1), 39-48. Retrieved from http://journals.cluteonline.com/index.php/JDM/article/view/4170

Resnick, L. B. (1987). The 1987 Presidential Address: Learning in School and out. Educational Researcher, 16(9), 1354. doi: $10.2307 / 1175725$

Richards, K. (2003). Qualitative inquiry in tesol. NY: Palgrave Macmillan.

Richmond, V. P. (1990). Communication in the classroom: Power and motivation. Communication Education, 39(3), 181-195. doi: 10.1080/03634529009378801

Richmond, V. P., \& McCroskey, J. C. (1984). Power in the classroom II: Power and learning. Communication Education, 33(2), 125-136. doi: 10.1080/03634528409384729

Rowden, R. W. (1995). The role of human resource development in successful small to mid-sized manufacturing businesses: A comparative case study. Human Resource Development Quarterly, 6(4), 355-373. doi: 10.1002/hrdq.3920060405

Rowden, R. W., \& Ahmad, S. (2010). The relationship between workplace learning and job satisfaction in small to midsized businesses in Malaysia. Human Resource Development International, 3(3), 307-322. doi:

$10.1080 / 13678860050128492$

Saldaña, J. (2012). The coding manual for qualitative researchers. (2nd ed.). London: SAGE Publications Ltd.

Scribner, S., \& Sachs, P. (1990). A study of on-the-job training. New York, N.Y.: National Center on Education and Employment, Teachers College, Columbia University.

Seawright, J., \& Gerring, J. (2008). Case selection techniques in case study research: A menu of qualitative and quantitative options. Political Research Quarterly, 61(2), 294-308. doi: 10.1177/1065912907313077

Shenton, A. K. (2004). Strategies for ensuring trustworthiness in qualitative research projects. Education for Information, 22, 63-75.

Shindler, J. (2009). Transformative classroom management: Positive strategies to engage all students and promote a psychology of success. San Francisco: Jossey-Bass.

Simons, M., Harris, R., \& Bone, J. (1999). Workplace trainers: what do they do? In E. Vocational \& A. Training Research Association (Eds.), Quality and diversity in VET research: proceedings of the second national conference of the Australian Vocational Education and Training Research Association, (AVETRA). (pp.287-294). Sydney: Australian Vocational Education and Training Research Association.

Skule, S. (2004). Learning conditions at work: a framework to understand and assess informal learning in the workplace. International Journal of Training and Development, 8(1), 8-20. doi: 10.1111/j.1360-3736.2004.00192.x 
Smith, P. J. (2003). Workplace Learning and Flexible Delivery. Review of Educational Research, 73(1), 53-88. doi: $10.2307 / 3516043$

Stasz, C., Eide, E. R., Martorell, F., Constant, L., Goldman, C. A., Moini, J. S., . . Salem, H. (2008). Post-Secondary Education in Qatar: Employer Demand, Student Choice, and Options for Policy (1 ed.): RAND Corporation.

Swanson, R.A. \& Falkman, S.K. (1997). Training delivery problems and solutions: Identification of novice trainer problems and expert trainer solutions. Human Resource Development Quarterly, 8(4), 305-314

Thomas, D. R. (2006). A general inductive approach for analyzing qualitative evaluation data. American Journal of Evaluation, 27(2), 237-246. doi: 10.1177/1098214005283748

Tynjälä, P. (2008). Perspectives into learning at the workplace. Educational Research Review, 3(2), 130-154. doi: http://dx.doi.org/10.1016/j.edurev.2007.12.001

Vaughan, K. (2008). The New Zealand Engineering Food \& Manufacturing Industry Training. Workplace learning: a literature review. Auckland: Competenz.

Williams, K. (2009). Exploring professional development practices for vocational education and training practitioners. Australian Journal of Teacher Education, 34(4), 1-15. Retrieved from http://dx.doi.org/10.14221/ajte.2009v34n4.1

Yin, R. K. (2003). Case study research: Design and methods. (3rd ed.). Thousand Oaks: SAGE Publications.

York, K. M. (2009). Applied human resource management: Strategic issues and experiential exercises. Thousand Oaks: SAGE Publications, Inc.

\section{Appendix 1}

\section{Interview Guide}

Title: The Neglected World of the Workplace Trainer

Time of the Interview: $20-30$ mins

Date :

Place :

Interviewer: Marwa Elshafie

Interviewee:

The research is a part of the researcher's Ed.D in education at Exeter University. It aims at exploring the world of the workplace trainers in Qatar. The consent has been taken from the manager to conduct these interviews.

I would like your consent on recording our conversation and the use of the data from the interviews in the assignment. I assure you that the confidentiality will be protected by not using any names and the deletion of the recording after the transcription.

You have the right to quit at any point whether during or after the interview. The estimate time for the interview is 30 minutes and it can be conducted in English or in Arabic.

Thank you for participation.

\section{Interview Questions}

1. How long have you been teaching in this institute?

What are you total years of experience in workplace training?

What are your qualifications? Any teaching/ training certificates?

2. experience with the employee as a learner? How is it different from your previous teaching experience?

3. How is your work different from the college instructor?

4. Tell me about your experience with the quality compliance in your institution.

5. Do you have any suggestions for improvement? 
Appendix 2

Informed Consent

The Neglected World of the Workplace Trainer

Marwa Elshafie

marwaasg@hotmail.com

I am currently doing my doctorate degree in education at Exeter University and this interview is part of my assignment. I would like your consent on recording this interview and quote from the data anonymously in my assignment. I assure you that the confidentiality will be protected by not using any names and the deletion of the recording after the transcription.

You have the right to quit at any point whether during or after the interview. The estimate time for the interview is 30 minutes.

If you agree on participation, could you kindly sign below.

Thank you.

Date

Signature of Interviewee 